\title{
The Description of Husband's Knowledge and Support of Giving Exclusive Breastfeeding in Mekargalih, Jatinangor, Indonesia
}

\author{
Refi Hanna Amelinda1, Sri Astuti ${ }^{2}$, and Anita Yuliani ${ }^{2}$ \\ ${ }^{1}$ Postgraduate Student Faculty of Public Health, Universitas Indonesia, Depok, Indonesia \\ ${ }^{2}$ Diploma Program in Midwifery, Faculty of Medicine, Padjadjaran University, Bandung, Indonesia
}

Corresponding Author:

Refi Hanna Amelinda

amelindarefihanna@gmail.com

Received: 26 December 2018

Accepted: 23 February 2019

Published: 7 March 2019

Publishing services provided by Knowledge E

(c) Refi Hanna Amelinda

et al. This article is distributed

under the terms of the

Commons Attribution License,

which permits unrestricted use and redistribution provided that the original author and source are credited

Selection and Peer-review under the responsibility of the 2 nd International Meeting of Public Health 2016 Conference Committee.

\section{Abstract}

Giving exclusive breastfeeding has excellent benefit either for mother or baby. Breastfeeding has natural and complete nutrition to be absorbed by baby and also protects baby from infection. Moreover, the cost spent by the mother to provide milk becomes cheaper than formula milk. This research aimed to know the description of the husband's knowledge and support in giving exclusive breastfeeding. The method used in this research was a cross-sectional approach. Population and research samples were all husband of pregnant mothers in Mekargalih, Jatinangor, Indonesia, as many as 60 people. Data collecting technique was total sampling, the research instrument was a questionnaire, and the data processing method was a univariate analysis displayed in the form of frequency and percentage distribution. The result was $48.3 \%$ of husbands that had knowledge and support in giving exclusive breastfeeding, and $51.7 \%$ of husbands that did not support in giving exclusive breastfeeding.

\section{Keywords: Breastfeeding; husband's support; husband's knowledge}

\section{Introduction}

Exclusive breastfeeding, according to WHO (2002), is giving only breast milk to the baby and not providing any other food or drink, including water, except medicines and vitamin or mineral drops. Breast milk dairy is also allowed, given to infants aged six months old. Breast milk has exclusive excellent benefits for both mother and baby. Breast milk contains nutrients that are complete, easily digestible, easily absorbed by the baby and also protects the baby from infection. Also, mothers spend less money on breast milk as compared to the formula milk (Riksani 2012).

In developing countries, more than 10 million infants died per year, as two-thirds of deaths associated with nutritional problems that could have avoided. Research done in 42 developing countries showed that exclusive breastfeeding for six months was public health interventions that had the most significant positive impact on lowering 
child mortality, which was about $13 \%$. WHO data represented that in the year of 2012, exclusive breastfeeding was only $37 \%$ and had fulfilled in 26 countries. On a national level, the coverage of exclusive breastfeeding in Indonesia was still low in 2010 with only 33.6\% of infants in Indonesia who were exclusively breastfed (Prametiol 2012).

The result of primary health research (Riskesdas) in 2010 stated that breastfeeding in Indonesia had reached $15.3 \%$ and formula feeding increased three times higher from $10.3 \%$ to $32.5 \%$, whereas the coverage of exclusive breastfeeding in 2013 increased by $30.2 \%$, not higher than the increasing of formula feeding in 2010 , amounting to $32.5 \%$. This figure is quite pathetic, public awareness in promoting breastfeeding is still relatively low, including lack of knowledge of pregnant wives, families, and communities in regards to the importance of breastfeeding (Depkes RI 2012; Kemenkes 2013)

Nowadays, giving the exclusive breastfeeding is lower than formula feeding. A husband who understands the importance of exclusive breastfeeding would be very supportive to his wife regarding exclusively breastfeed their children. Therefore mothers will be motivated and will give the exclusive breastfeeding (Kemenkes 2013).

Lack of support from people nearby or husband is one of the factors that lead to becoming less motivated to breastfeed her baby, while a mother whose husband always encourages her in exclusive breastfeeding is likely to become highly motivated and will breastfeed the baby for no less than six months (Riksani 2012).

The development of a husband's support is closely associated with exclusive breastfeeding to infants, and couldn't separate from husband's knowledge regarding the importance of exclusive breastfeeding for infants. Husband's knowledge becomes one of the primary reason regarding his awareness to encourage his wife to breastfeed exclusively for the sake of baby's growth (Riksani 2012).

JDPT Health Center Jatinangor located in Sumedang had a working area of 12 villages, 130 community groups, 473 neighborhoods, 21,669 households and a population of 87,238 inhabitants live in Jatinangor. The number of integrated service post in Indonesia, known as Posyandu in Jatinangor, were 118 Posyandu, with 6,687 toddlers, consisting of aged 0 - to 1 - year old reaching 1.430 babies and aged one- to five-year-old reaching 5.457 toddlers. Common diseases suffered by infants at age zero- to one-year-old were diarrhea, which was still strongly influenced by the nutritional status and the environment. The number of infants at the age of less than a year suffering from diarrhea was 131 babies. Six months old infants suffering from diarrhea were still strongly influenced by the nutritional status especially on exclusive breastfeeding. Breastfeeding is essential for the optimal development of physical, mental and intelligence for the infants (Pendataan Kecamatan Jatinangor 2012). 
Coverage data of exclusive breastfeeding at the Health Center in Jatinangor in the year 2012 was approximately 62.7\%, while in Mekargalih was about 77.4\%. This was not as expected by the Ministry of Health targeting to achieve $80 \%$. Exclusive breastfeeding was influenced by the involvement of husband (Pendataan Kecamatan Jatinangor 2012).

Research conducted by Ariesta \& Sabarwati (2009) showed about the husband's knowledge about the practice of breastfeeding infants in Beji village, East Depok. The study showed out of 36 respondents there were $52.5 \%$ of respondents who had a high level of knowledge and the remaining $47.5 \%$ had a low level of expertise (Syamsiah 2011).

This study aimed to look at how vital the husbands' support given to the pregnant wives were and to demonstrate the relationship between husbands' support and the continuity of exclusive breastfeeding, so the wives were able to provide optimal breast milk without any additional food for six months.

\section{Methods}

\subsection{Research design}

This research was a cross-sectional study in which the data concerning all kinds of variables were collected at the same time. The population in this study was the husbands of pregnant wife trimester I, II, and III with the number of 60 people.

Participants were taken overall in the Mekargalih, Jatinangor - Sumedang. The number of participants in this study was 60 people. Sampling technique in this study was a total sampling. The variable in this study was the husbands of pregnant wives' knowledge and support in regards to exclusive breastfeeding.

\subsection{Data collection technique}

The data used in this study were primary data. The data were collected using questionnaire filled out by respondents who fit the criteria of inclusion. The husbands of pregnant wives who live in the Mekargalih got informed consent before filling out surveys. Based on the data obtained from the questionnaires given to respondents who became participants, a test on the poll was performed to measure the quality of the inquiry. Afterward, the analysis of the validity and reliability of the questionnaire was completed.

According to Sugiono (2011), before conducting research, the instruments must be tested before the participants with the same characteristics. The number of respondents 
in the validity test was 26 people. An instrument was considered valid and could measure the variables if the coefficient value was equal to or above 0.3.

According to Arikunto (2010), the alpha formula used as instrumental support of the reliability test. Alpha formula was applied to find the instrument reliability which scores were not one nor 0 , for example, a questionnaire or detailed questions.

The number of respondents who were included in the reliability test was 26 people. An instrument was considered reliable and could measure the variables if the coefficient value was equal to or above 0.70 (Sugiono 2010).

TABLE 1: Validity dan Reliability Result on Knowledge Questionnaire.

\begin{tabular}{|l|c|c|}
\hline No. & $\begin{array}{c}\text { Validity Coeff. } \\
\text { (ppb) }\end{array}$ & Notes \\
\hline 1 & 0.512 & Valid \\
\hline 2 & 0.512 & Valid \\
\hline 3 & 0.494 & Valid \\
\hline 4 & 0.512 & Valid \\
\hline 5 & 0.494 & Valid \\
\hline 6 & 0.380 & Valid \\
\hline 7 & 0.743 & Valid \\
\hline 8 & 0.489 & Valid \\
\hline 9 & 0.773 & Valid \\
\hline 10 & 0.494 & Valid \\
\hline 11 & 0.380 & Valid \\
\hline 12 & 0.477 & Valid \\
\hline 13 & 0.513 & Valid \\
\hline 14 & 0.439 & Valid \\
\hline 15 & 0.387 & Valid \\
\hline R-Alpha & 0.795 & Reliable \\
\hline Cronbach & & \\
\hline
\end{tabular}

\subsection{Knowledge data analysis}

Techniques used in data processing in regards to knowing in this study was percentages added up in every alternative or choice answer on any question, then compared to the maximum value and multiplied by one hundred percent using the formula:

$$
P=\frac{f}{N} \times 100 \%
$$

Notes:

$$
\begin{aligned}
& P=\text { percentage } \\
& f=\text { the value obtained }
\end{aligned}
$$


TABLE 2: Validity dan Reliability Result on Husbands' Support Questionnaire.

\begin{tabular}{|l|c|c|}
\hline No. & Validity Coeff. (r) & Notes \\
\hline 1 & 0.388 & Valid \\
\hline 2 & 0.764 & Valid \\
\hline 3 & 0.469 & Valid \\
\hline 4 & 0.455 & Valid \\
\hline 5 & 0.595 & Valid \\
\hline 6 & 0.357 & Valid \\
\hline 7 & 0.377 & Valid \\
\hline 8 & 0.624 & Valid \\
\hline 9 & 0.606 & Valid \\
\hline 10 & 0.562 & Valid \\
\hline 11 & 0.575 & Valid \\
\hline 12 & 0.496 & Valid \\
\hline R-Alpha & 0.732 & Reliable \\
\hline Cronbach & & \\
\hline
\end{tabular}

$\mathrm{N}=$ the maximum value of the total number of respondents

According to Sugiono (2003), the correct answer gives a score of 1 and a wrong answer gives a rating of 0 . The result of the mother's knowledge, when the mother answered the questions correctly by $76-100 \%$, means good, $56-75 \%$ means enough, and if below 56\%, it means less (Syamsiah 2011).

\subsection{Supportive data analysis}

To categorize the husbands' support, the mean of the following data first was calculated as shown below:

$x \geq$ means support,

$x<$ mean it does not support

\section{Results}

The result of husbands' knowledge in regards to exclusive breastfeeding was shown in the frequency distribution table 3. 
TABLE 3: Frequency Distribution Table of Husbands' Knowledge in regards to Exclusive Breastfeeding.

\begin{tabular}{|l|c|c|}
\hline $\begin{array}{l}\text { Husbands' Knowledge in } \\
\text { regards to Exclusive } \\
\text { Breastfeeding }\end{array}$ & F & $\%$ \\
\hline Good & 21 & 35 \\
\hline Enough & 29 & 48.3 \\
\hline Less & 10 & 16.7 \\
\hline Total & $\mathbf{6 0}$ & $\mathbf{1 0 0}$ \\
\hline
\end{tabular}

\subsection{Husbands' support to their pregnant wives in regards to exclu- sive breastfeeding}

The result of husbands' support in regards to exclusive breastfeeding was shown in frequency distribution Table 4.

TABLE 4: Frequency Distribution of Husbands' Support in regards to Exclusive Breastfeeding.

\begin{tabular}{|l|c|c|}
\hline $\begin{array}{l}\text { Husbands' Support in regards } \\
\text { to Exclusive Breastfeeding }\end{array}$ & $\mathbf{f}$ & $\%$ \\
\hline Support & 29 & 48.3 \\
\hline Does not support & 31 & 51.7 \\
\hline Total & $\mathbf{6 0}$ & $\mathbf{1 0 0}$ \\
\hline
\end{tabular}

\section{Discussion}

\subsection{Husbands' knowledge to their pregnant wives in regards to exclusive breastfeeding in Mekargalih}

The result of this study showed that the respondents' awareness in regards to exclusive breastfeeding was mostly categorized as enough knowledge (48.3\%), and less knowledge (16.7\%). In contrast to the results of research conducted by Siti Syamsiah (2012), the data indicated that the husbands of pregnant wives with profound knowledge were $55 \%$. Meanwhile, the husbands of pregnant wives with poor knowledge were $45 \%$. The results showed that the level of knowledge regarding exclusive breastfeeding was quite high. It was in line with research conducted by Ariesta \& Sabarwati (2009). This team researched husbands' knowledge about breastfeeding infants practice in Beiji village, East Depok. The study represented that out of 36 respondents, $52.5 \%$ of respondents had a high level of knowledge, and the remaining of $47.5 \%$ had a low level of knowledge. The cause of different characteristics and different levels of education was the area of research (Syamsiah 2011). 


\subsection{Husbands' support to their pregnant wives in regards to exclu- sive breastfeeding}

Based on the results, 29 respondents (48.3\%) supported their wives in exclusive breastfeeding, while 31 respondents (51.7\%) did not. The results obtained from the interview showed that the husband helped his wife in exclusive breastfeeding because they were aware of so many benefits gained in exclusive breastfeeding both for children and his wife. Also, the husband knew not only that exclusive breastfeeding saved money, but also his children would be healthier if they gave breast milk rather than formula milk - however, the majority of husbands whose wives worked disagreed in exclusive breastfeeding because the wives who worked did not have time to breastfeed the child at home.

Support given by a husband to his wife included psychological support, physical, information, and environment. For instance, psychological help from the husbands could provide as motivation, reminder. The husbands should always listen to their wives' complaints regarding exclusive breastfeeding. Physical support the husbands that could do was by doing the house chores so their wives could have a short break in preparation for lactation purposes such as cleaning the breasts and so forth. The husbands of pregnant wives could do educational support by buying or providing a book or magazine on the preparation of exclusive breastfeeding.

\section{Conclusions}

Based on the result and discussion, it could be concluded that the characteristic of husbands of pregnant wives (respondents) in Mekargalih were mostly between the age of 31- to 40-year old, the highest education level was high school and the lowest education level was elementary school, and most respondents work as a self-employed worker. Most of the husbands of pregnant wives had enough knowledge regarding exclusive breastfeeding. As many as $51.7 \%$ husbands of pregnant wives did not support exclusive breastfeeding.

\section{Acknowledgment}

In this study, the authors would like to thank stakeholders at Padjadjaran University who helped and to all parties involved in the Mekargalih who provided an opportunity for the authors to conduct research. 


\section{References}

[1] Departemen Kesehatan RI. 2012. ASI dan makanan tambahan. Jakarta: Direktorat Jendral Gizi dan Kesehatan Ibu dan Anak.

[2] Kementerian Kesehatan Republik Indonesia. 2013. Riset kesehatan dasar 2013. Jakarta: Badan Litbangkes.

[3] Notoatmodjo, Soekidjo. 2010. Metodologi penelitian kesehatan.

[4] Pendataan Keluar Tahun 2012 (Kantor Kecamatan Jatinangor)

[5] Prametiol. 2012. Minimnya ruang laktasi jadi terkendala kelancaran ASI.

[6] Riksani, Ria. 2012. Keajaiban ASI (Air susu ibu). Jakarta: Dunia Sehat.

[7] Sugiono, H. B. 2001. Statistik Non Parametris untuk Penelitian. Bandung: Alfabeta.

[8] Sugiyono. 2000. Metode penelitian administrasi Bandung: Alfabeta.

[9] Sugiyono. 2003. Statistika Untuk Penelitian. Bandung: Alfabeta.

[10] Syamsiah, Siti. 2011. "Tingkat Pengetahuan Suami Mengenai ASI Eksklusif dan Hubungannya Dengan Penerapan Breastfeeding Father." Jurnal Kesehatan Prima Vol 3 (1). 